\title{
Pengembangan Perangkat Pembelajaran Biologi Berbasis Keterampilan Proses Sains pada Kelas X IPA SMA Negeri 2 Majene
}

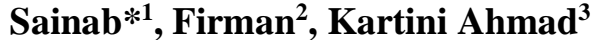 \\ 1,2,3FKIP Universitas Sulawesi Barat \\ ${ }^{* 1}$ sainabruddin@gmail.com, ${ }^{2}$ firorahman88@gmail.com, ${ }^{3}$ kartiniahmad97@gmail.com
}

\begin{abstract}
Abstrak
Penelitian ini bertujuan untuk mengetahui kepraktisan dan keefektifan dari perangkat pembelajaran biologi berbasis Keterampilan Proses Sains di kelas X IPA SMA Negeri 2 Majene. Jenis penelitian ini adalah jenis penelitian pengembangan (Research and Development) dengan menggunakan model pengembangan dari Tjeerd Plomp, yang terdiri dari beberapa fase yaitu (1) fase investigasi awal, (2) fese desain, (3) realisasi, (4) fase tes, evaluasi dan revisi, dan (5) fase implementasi. Instrumen yang digunakan dalam pengumpulan data penelitian dibagi atas tiga yaitu lembar validasi, lembar observasi keterlaksanaan perangkat, dan angket respon siswa. Data yang diperoleh kemudian dianalisis dengan menggunakan analisis data deskriptif. Berdasarkan hasil uji kevalidan dari para ahli dengan menggunakan koefisien validasi isi untuk perangkat pembelajaran memperoleh rata-rata yaitu 3,50. Untuk kepraktisan perangkat pembelajaran diperoleh dari pengamatan keterlaksanaan perangkat pembelajaran 3,70 sedangkan untuk keefektifan perangkat pembelajaran diperoleh dari angket respon peserta didik 2,87, proses ini mengindikasikan bahwa perangkat pembelajaran yang dikembangkan layak untuk digunakan. Untuk uji keefektifan perangkat pembelajaran yang dikembangkan, diperoleh rata-rata ketuntasan belajar peserta didik adalah 78,24\% yang mengindikasikan bahwa perangkat pembelajaran memenuhi kategori keefektifan dengan jumlah 25 orang peserta didik. Berdasarkan dari hasil penelitian menunjukkan bahwa perangkat pembelajaran berbasis keterampilan proses sains pada mata pelajaran biologi di kelas X IPA 3 yang dikembangkan memenuhi kriteria valid, praktis, dan efektif.
\end{abstract}

Kata kunci: Pengembangan, Perangkat pembelajaran biologi, Keterampilan proses sains

\section{PENDAHULUAN}

Perangkat pembelajaran merupakan salah satu alat penunjang keberhasilan pembelajaran. Isi perangkat pembelajaran tertuang rencana proses pembelajaran, penilaian, media, dan metode yang akan digunakan dalam pembelajaran. Perencanaan perangkat pembelajaran yang baik akan berpengaruh pada pelaksanaan pembelajaran yang sukses. Perangkat pembelajaran yang digunakan guru saat ini masih belum tepat penyusunannya. Guru kesulitan menentukan alokasi waktu pembelajaran, perumusan indikator pencapaian kompetensi dan menentukan metode pembelajaran sehingga dalam penyusunan perangkat pembelajaran hanya berdasarkan persepsi masing-masing guru.

Kinasih (2017), mengemukakan bahwa keterbatasan waktu yang dimiliki guru karena tugas dan tanggung jawab yang banyak mengakibatkan waktu guru dalam penyusunan perangkat pembelajaran menjadi kurang.Peserta didik dalam pembelajaran biologi dituntut untuk lebih mengetahui penciptaan situasi dan kondisi yang kondusif agar terjadi interaksi antara subjek didik dengan objek belajarnya yaitu mahluk hidup dan segala aspek kehidupannya. Perangkat pembelajaran yang dibutuhkan harus menggunakan metode atau model yang merangsang pemikiran peserta didik untuk mengembangkan kemampuan-kemampuan mendasar yang telah ada dalam diri peserta didik.

Hapsari (2017), mengemukakan bahwa adapun masalah yang berkaitan dengan permasalahan pada perangkat pembelajaran biologi antara lain guru kurang mampu menyusun bahan ajar sendiri, guru

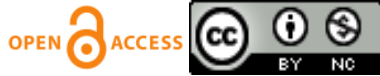


https://jurnal.unsulbar.ac.id/index.php/saintifik

mengajarkan materi-materi secara langsung dari buku paket dan lembar kegiatan peserta didik (LKPD) yang diperjualbelikan, sehingga guru mengajar tidak berpanduan pada standar kompetensi (SK) dan kompetensi dasar (KD) tetapi pada buku paket yang ada.

Fakta lain yang sama dengan masalah diatas adalah sebagian besar guru-guru pada saat proses pembelajaran biologi di sekolah masih mengikuti metode konvensional. Metode ceramah masih menjadi cara yang dipilih oleh guru-guru untuk menyelesaikan pembelajaran kurikulum, karena dengan menggunakan metode tersebut guru tidak perlupersiapan perangkat pembelajaran secara lengkap dan detail. Sehingga peserta didik cenderung diam, malu bertanya dalam setiap kesempatan pembelajaran biologi, yang seharusnyadalam proses pembelajaran biologi di SMA cenderung mengedepankan peserta didik lebih aktif dan kreatif.

Dewi (2018), mengemukakan bahwa metode konvensional merupakan langkah operasional dari strategi pembelajaran yang dipilih untuk mencapai tujuan pembelajaran karena penggunaan metode tersebut membantu guru dalam meningkatkan efektifitas dan efesiensi proses belajar mengajar. Metode konvensional akan menjadi semakin sempurna apabila di kembangkan dengan memadukan metode tersebut dengan metode modern, sehingga terjadi informasi antara guru dan peserta didik, mudah mengomunikasikan efektif dan efisien dalam mengadopsi dan sharing terhadap pembelajaran yang diterima dan diberikan. Penerapan metode konvensional yang tidak dikembangkan tidak dapat membantu peserta didik dalam mengembangkan kemampuan ilmiahnya.

Hasil observasi di SMA Negeri 2 Majene mengemukakan bahwa guru belum pernah mengembangkan dan menggunakan desain pembelajaran berbasis keterampilan proses sains, begitu pula hasil wawancara denganpeserta didik program pengalaman lapangan (PPL) biologi di SMA Negeri 2 Majene mengemukakan bahwa pembelajaran di sekolah tersebut belum efektif dalam penyelesaian pembelajaran kurikulum, dan nilairata-rata ulangan harian belum memuaskan. $85 \%$ peserta didik diantaranya memiliki nilai di bawah kriteria ketuntasan minimal (KKM) yaitu 75, sehingga dari hasil wawancara tersebut guru merasa tertarik untuk mencoba desain keterampilan proses sains untuk pembelajaran.

\section{METODE PENELITIAN}

Penelitian ini dilaksanakan pada semester genap tahun ajaran 2018/2019, terhitung mulai April sampai dengan Mei tahun 2019 di SMA Negeri 2 Majene, Jln. Khairil Anwar, Kelurahan Lembang, Kecamatan Banggae Timur, Kabupaten Majene. Subjek uji coba produk hasil penelitian adalah kelas X IPA 3 SMA Negeri 2 Majene. Model penelitian dan pengembangan yang digunakan adalah model pengembangan jenis penelitian Plomp. Menurut Semmel dalam Trianto (2010), tahapan kegiatan dari penelitian Plomp yaitu dari fase investigasi awal (prelimenary investigation), fase desain (design), fase realisasi/konstruksi (realization/construction), dan fase tes, evaluasi dan revisi (test, evaluation and revision) dan implementasi (implementation).

Teknik pengumpulan dari hasil validasi perangkat pembelajaran (RPP, LKPD, THB) dilakukan dengan cara membagikan perangkat pembelajaran dan lembar validasi kepada para ahli dan praktisi (validator). Selanjutnya para validator memberikan penilaian berdasarkan pertanyaan dan pernyataan untuk masing-masing indikator penilaian yang tersedia. Data uji kepraktisan diperoleh dari hasil instrumen penelitian berupa lembar observasi keterlaksanaan perangkat pembelajaran. Selanjutnya lembar observasi keterlaksanaan tersebut dibagikan ke guru mata pelajaran biologi dan salah satu teman yang menjadi pengamat, kemudian hasil lembar observasi keterlaksanaan tersebut digunakan untuk mengetahui apakah produk hasil penelitian dapat diterapkan dalam pembelajaran di kelas.

Data uji keefektifan diperoleh dari hasil pembagian angket respon untuk peserta didik, melihat ratarata hasil tes belajar seluruh peserta didik pada kelas yang menggunakan perangkat pembelajaran yang telah dikembangkan, dan telah mencapai ketuntasan minimal dan termasuk kriteria nilai baik. Data hasil validasi para ahli untuk masing-masing perangkat pembelajaran dianalisis dengan mempertimbangkan masukan,

Pengembangan Perangkat Pembelajaran Biologi Berbasis Keterampilan Proses Sains pada Kelas X IPA 
https://jurnal.unsulbar.ac.id/index.php/saintifik

komentar dan saran-saran dari para validator. Hasil analisis tersebut disajikan sebagai pedoman untuk merevisi perangkat pembelajaran (RPP, LKPD, THB).

Analisis data kepraktisan berupa data hasil keterlaksanaan perangkat pembelajaran dilakukan terhadap penilaian dari kedua observer yang mengamati keterlaksanaan kegiatan tersebut. Dari hasil penilaian observer, ditentukan nilai rata-rata $\mathrm{T}$. Nilai $\mathrm{T}$ selanjutnya dikonfirmasikan dengan interval penentuan kategori keterlaksanaan perangkat pembelajaran yaitu:

$$
\begin{array}{ll}
\mathrm{T} \leq 1 & =\text { Tidak Terlaksana } \\
1<\mathrm{T} \leq 2 & =\text { Sebagian Kecil Saja Terlaksana } \\
2<\mathrm{T} \leq 3 & =\text { Sebagian Besar Terlaksana } \\
3<\mathrm{T} \leq 4 & =\text { Terlaksana Keseluruhan }
\end{array}
$$

(Asdar dalam Arianti, 2017).

Angket respon peserta didik yang selanjutnya dianalisis dengan persentase. Kegiatan yang dilakukan untuk menganalisis data respon peserta didik. Menentukan kategori validasi setiap kriteria (Ki) atau rerata aspek (Ai) atau rerata total (Xi) dengan kategori validasi yang telah ditetapkan.

Tabel 1 Kriteria Penilaian Respon Peserta didik

\begin{tabular}{|c|c|}
\hline Nilai & Kriteria \\
\hline $3,5 \leq \mathrm{Xi} \leq 4$ & Sangat positif \\
\hline $2,5 \leq \mathrm{Xi} \leq 3,5$ & Positif \\
\hline $1,5 \leq \mathrm{Xi} \leq 2,5$ & Cukup positif \\
\hline $0 \leq \mathrm{Xi} \leq 1,5$ & Tidak positif \\
\hline
\end{tabular}

(Riduan dalam Arianti, 2017)

Mengkategorisasikan kemampuan peserta didik, berdasarkan teknik kategorisasi standar yang ditetapkan oleh departemen pendidikan dan kebudayaan, sebagai berikut:

Tabel 2 Kriteria hasil belajar

\begin{tabular}{|c|c|c|}
\hline No & Tingkat penguasaan & Kategori \\
\hline 1. & $85-100$ & Sangat Tinggi \\
\hline 2. & $65-84$ & Tinggi \\
\hline 3. & $55-64$ & Sedang \\
\hline 4. & $35-54$ & Rendah \\
\hline 5. & $9-34$ & Sangat Rendah \\
\hline
\end{tabular}

(Astuti, 2017)

\section{HASIL DAN PEMBAHASAN}

\subsection{Hasil}

Kegiatan ini bertujuan untuk menetapkan masalah yang menjadi dasar dalam pengembangan perangkat pembelajaran. Masalah mendasar yang perlu mendapat perhatian adalah bagaimana perangkat pembelajaran yang selama ini dilaksanakan oleh peserta didik kelas X IPA 3 SMA Negeri 2 Majene, dan bagaimana menciptakan suasana pembelajaran yang menyenangkan dan memungkinkan peserta didik untuk mengkonstruksi pemahamannya terhadap materi yang diajarkan. 
https://jurnal.unsulbar.ac.id/index.php/saintifik

\subsubsection{Hasil Fase Perancangan (Design)}

Tahap ini dihasilkan rancangan perangkat pembelajaran. Tahap perancangan bertujuan untuk merancang perangkat pembelajaran (RPP, LKPD, dan THB) yang dikembangkan dengan mempertimbangkan hasil investigasi awal.

\subsubsection{Hasil Fase Realisasi}

Tahap ini merupakan lanjutan dari kegiatan pada tahap perancangan. Pada fase ini produk yang dihasilkan adalah perangkat pembelajaran berbasis keterampilan proses sains. Selanjutnya perangkat pembelajaran tersebut disebut prototipe 1 (awal) sebagai hasil perancangan model.

Hasil-hasil kontruksi diteliti kembali apakah perangkat pembelajaran berbasis keterampilan proses sains tersebut mampu memfasilitasi peserta didik dalam melakukan pembelajaran. Dengan demikian, perangkat pembelajaran berbasis keterampilan proses sains tersebut siap diuji valid tidaknya oleh para ahli. Untuk semua hasil dari produk prototipe I.

\subsubsection{Fase Tes, Evaluasi dan Revisi}

\subsubsection{Fase Tes}

Para ahli diminta untuk memvalidasi semua perangkat pembelajaran yang telah dihasilkan pada tahap perancangan (Draf 1). Selanjutnya saran-saran dari para validator digunakan sebagai bahan pertimbangan dan landasan untuk melakukan revisi perangkat sehingga diperoleh perangkat prototipe. Perangkat pembelajaran yang telah divalidasi dapat dideskripsikan sebagai berikut:

Tabel 3 Hasil validasi perangkat pembelajaran

\begin{tabular}{|c|l|c|c|}
\hline Perangkat & \multicolumn{1}{|c|}{ Aspek Penilain } & Hasil Penilaian & Kategori \\
\hline \multirow{5}{*}{ RPP } & Format RPP & 3,50 & Sangat Valid \\
\cline { 2 - 4 } & Isi (materi) RPP & 3,33 & Valid \\
\cline { 2 - 4 } & Indikator & 4 & Sangat Valid \\
\cline { 2 - 4 } & Waktu & 3,75 & Sangat Valid \\
\cline { 2 - 4 } & Metode/kegiatan pembelajaran & 3,40 & Valid \\
\cline { 2 - 4 } & Bahasa & 3,67 & Sangat Valid \\
\hline \multirow{5}{*}{ LKPD } & Format LKPD & 3,33 & Valid \\
\cline { 2 - 4 } & Isi LKPD & 3,63 & Sangat Valid \\
\cline { 2 - 4 } & Melibatkan Indikator & 4 & Sangat Valid \\
\cline { 2 - 4 } & Bahasa LKPD & 3,50 & Sangat Valid \\
\cline { 2 - 4 } & Format LKPD & 3,33 & Valid \\
\hline \multirow{5}{*}{ THB } & Materi soal & 3,33 & Sangat Valid \\
\cline { 2 - 4 } & Melibatkan Indikator & 3,50 & Sangat Valid \\
\cline { 2 - 4 } & Kontruksi & 3,75 & Sangat Valid \\
\cline { 2 - 4 } & Bahasa & 3,50 & \\
\cline { 2 - 4 } & Waktu & 3,38 & $\mathbf{3 , 5 6}$ \\
\hline \multirow{5}{*}{ Rata-rata total } & & & Sangald \\
\hline
\end{tabular}

Tahap proses pengembangan instrumen ini terdapat beberapa instrumen pengumpulan data yang dikembangkan melalui proses validasi. Instrumen yang dimaksud adalah lembar keterlaksanaan pembelajaran, dan lembar respon peserta didik.

Tabel 4 Hasil penilaian validator terhadap instrumen Penelitian yang dikembangkan 
https://jurnal.unsulbar.ac.id/index.php/saintifik

\begin{tabular}{|c|l|c|c|}
\hline No & \multicolumn{1}{|c|}{ Instrumen Penilaian } & $\boldsymbol{X}$ & Keterangan \\
\hline 1 & $\begin{array}{l}\text { Lembar observasi keterlaksanaan } \\
\text { perangkat pembelajaran }\end{array}$ & 3,78 & Sangat Valid \\
\hline 2 & $\begin{array}{l}\text { Lembar angket respon peserta didik } \\
\text { terhadap perangkat pembelajaran }\end{array}$ & 3,5 & Sangat Valid \\
\hline
\end{tabular}

\subsubsection{Fase Evaluasi}

Fase evaluasi bertujuan untuk mengetahui kepraktisan dan keefektifan perangkat pembelajaran biologi berbasis keterampilan proses sains. Adapun metodenya yaitu dengan memberikan angket respon peserta didik kepada peserta didik yang berisikan tentang pertanyaan yang memiliki keterkaitan dengan proses pembelajaran berbasis keterampilan proses sains dan lembar observasi keterlaksanaan kepada observer untuk mengetahui sejauh mana kegiatan terlaksana dalam proses pembelajaran.

1) Uji coba Keefektifan

Tabel 5 Hasil respon peserta didik

\begin{tabular}{|c|l|c|c|}
\hline No & Responden & Rata-rata & Kategori \\
\hline 1. & Responden 1 & 3,31 & Positif \\
\hline 2. & Responden 2 & 2,89 & Positif \\
\hline 3. & Responden 3 & 3,0 & Positif \\
\hline 4. & Responden 4 & 2,72 & Positif \\
\hline 5. & Responden 5 & 2,82 & Positif \\
\hline 6. & Responden 6 & 2,58 & Positif \\
\hline \multicolumn{2}{r|}{ Total Rata-rata } & $\mathbf{2 , 8 8}$ & Positif \\
\hline
\end{tabular}

Tabel 6 Hasil tes hasil belajar (THB)

\begin{tabular}{|c|l|c|c|}
\hline No & \multicolumn{1}{|c|}{ Nama } & Nilai & Kategori \\
\hline 1. & MR & 76 & Tinggi \\
\hline 2. & ND & 76 & Tinggi \\
\hline 3. & NL & 80 & Tinggi \\
\hline 4. & NF & 62 & Sedang \\
\hline 5. & ZY & 44 & Rendah \\
\hline 6. & HAA & 82 & Tinggi \\
\hline \multicolumn{2}{|c|}{ Total Rata-rata } & $\mathbf{7 0}$ & Tinggi \\
\hline
\end{tabular}

2) Uji coba kepraktisan

Tabel 7 Hasil uji coba kepraktisan

\begin{tabular}{|c|c|c|c|}
\hline No & Responden & Rata-rata & Kategori \\
\hline 1. & Observer 1 & 3,36 & Terlaksana \\
\hline 2. & Observer 2 & 3,74 & Terlaksana \\
\hline \multicolumn{2}{|r|}{ Total Rata-rata } & $\mathbf{3 , 5 5}$ & Terlaksana \\
\hline
\end{tabular}

\subsubsection{Kegiatan revisi}

Kegiatan hasil evaluasi akan dipertimbangkan untuk menghasilkan perangkat pembelajaran berbasis keterampilan proses sains yang telah siap digunakan dalam lingkup kelas X IPA SMA Negeri 2

Pengembangan Perangkat Pembelajaran Biologi Berbasis Keterampilan Proses Sains pada Kelas X IPA 
https://jurnal.unsulbar.ac.id/index.php/saintifik

Majene, khususnya peserta didik kelas X IPA 3 SMA Negeri 2 Majene. Setelah dilakukan uji coba terbatas dan evaluasi tersebut maka menghasilkan produk perangkat pembelajaran berbasis keterampilan proses sains yang disebut prototipe II.

\subsubsection{Fase Implementasi}

Perangkat pembelajaran biologi berbasis keterampilan proses sains pada fase ini telah melalui fase tes, evaluasi, dan revisi. Dimana telah dilakukan uji coba terbatas dan mendapatkan perangkat pembelajaran yang efektif dan praktis.Produk dalam fase ini menggunakan perangkat pembelajaran yang sudah di uji coba dan direvisi sehingga menghasilkan produk akhir yang siap dibagikan dalam skala besar yakni kelas X IPA 3 SMA Negeri 2 Majene. Pengumpulan data kepraktisan perangkat pembelajaran biologi berbasis keterampilan proses sainsdiperoleh dengan cara memberikan lembar observasi keterlaksanaan kepada 2 observer sebagai pengamat.

Tabel 8 Hasil analisis data kepraktisan

\begin{tabular}{|l|r|r|r|r|r|r|r|r|}
\hline \multirow{2}{*}{} & \multicolumn{2}{|c|}{ P1 } & \multicolumn{2}{c|}{ P2 } & \multicolumn{2}{c|}{ P3 } & \multicolumn{2}{c|}{ P4 } \\
\cline { 2 - 9 } & O1 & O2 & O1 & O2 & O1 & O2 & O1 & O2 \\
\hline Rata-rata & 3,68 & 3,68 & 3,68 & 3,74 & 3,68 & 3,74 & 3,68 & 3,74 \\
\hline Rata-rata setiap pertemuan & \multicolumn{3}{|c|}{3,68} & \multicolumn{3}{|c|}{3,71} & \multicolumn{2}{|c|}{3,71} \\
\hline Total & \multicolumn{8}{|c|}{3,70} \\
\hline
\end{tabular}

Pengumpulan data keefektifan perangkat pembelajaran biologi berbasis keterampilan proses sainsdiperoleh dengan cara membagikan angket respon peserta didik kepada peserta didik observer sebagai responden.

Tabel 9 Hasil analisis data keefektifan

\begin{tabular}{|l|c|}
\hline Jumlah & 77,59 \\
\hline Rata-rata total & 3,10 \\
\hline Kategori & Sangat Positif \\
\hline
\end{tabular}

\subsection{Pembahasan}

Pengembangan perangkat pembelajaran biologi dilaksanakan secara bertahap untuk menghasilkan produk perangkat pembelajaran yang baik dan layak digunakan dalam proses pembelajaran. Model pengembangan yang digunakan untuk mengembangkan perangkat pembelajaran tersebut adalah Plomp dalam Trianto (2010) yang terdiri dari beberapa fase yaitu (1) fase investigasi awal, (2) fese desain, (3) realisasi, (4) fase tes, evaluasi dan revis, dan (5) fase implementasi.

Perangkat pembelajaran yang telah dikembangkan menjadi perangkat pembelajaran biologi berbasis keterampilan proses sains telah melalaui proses validitas yang dilakukan oleh validator ahli. Validitas dilakukan oleh dua validator, yang kemudian memvaliditas perangkat pembelajaran berbasis keterampilan proses sains yang dikembangkan dengan menggunakan lembar validitas yang telah disiapkan oleh peneliti. Uji tersebut menggunakan instrumen berupa lembar validitas.

Tingkat kepraktisan diukur dengan menggunakan lembar observasi keterlaksanaan pada tahap uji coba terbatas. Analisis hasil observasi terhadap aktivitas peserta didik terdiri dari 19 butir pernyataan terkait tentang keterampilan dalam proses pembelajaran. Observasi dilakukan dengan membagi lembar observasi keterlaksanaan perangkat pelajaran kepada 2 Observer. Berdasarkan lembar observasi yang diisi oleh observer yang ikut mengamati proses pembelajaran diperoleh data bahwa peserta didik aktif dalam melaksanakan proses pembelajaran menggunakan perangkat pembelajaran yang dikembangkan sehingga semua kegiatan terlaksana. 
https://jurnal.unsulbar.ac.id/index.php/saintifik

Tingkat keefektifan diukur dengan menggunakan angket respon peserta didik pada tahap uji coba terbatas. Angket respon peserta didik terdiri dari 29 butir pernyataan diantaranya yaitu: respon terhadap perangkat pembelajaran dan proses pembelajaran, respon terhadap Lembar Kerja Peserta Didik (LKPD) dan Tes Hasil Belajar (THB), respon terhadap Tes Hasil Belajar (THB).

\section{KESIMPULAN}

Tingkat validitas perangkat pembelajaran biologi berbasis keterampilan proses sains adalah 3,56 dengan kategori sangat tinggi. Tingkat kepraktisan perangkat pembelajaran biologi berbasis keterampilan proses sains adalah 3.70 sehingga praktis untuk digunakan, karena kegiatan pada proses pembelajaran dapat terlaksana. Tingkat keefektifan perangkat pembelajaran biologi berbasis keterampilan proses sains adalah 3,10 dan rata-rata hasil belajar peserta didik 78,24 sehingga efektif untuk digunakan berdasarkan respon yang positif yang diperoleh dari peserta didik.

\section{DAFTAR PUSTAKA}

Astuti, N. P. 2017. Pengembangan Perangkat Pembelajaran Berbasis Keterampilan Informasi Pada Mata Pelajaran Biologi Materi Sistem Respirasi Di Kelas XI IPA SMAN 2 Sungguminasa Kabupaten Gowa.Skripsi (Online).http://respositori.uin.alauddin.ac.id.pdf (Diakses pada tanggal 20 Januari 2019).

Arianti, Winda, 2017. Pengembangan Penuntun Praktikum Kimia Dasar Untuk Mahasiswa Pendidikan Biologi Universitas Islam Negeri (UIN) Alauddin Makassar.Skripsi (Online).http://repositeri.uinalauddin.ac.id/7184/1/WIDA/ 20ARIANTI.pdf (Diakses pada tanggal 20 Januari 2019).

Dewi, Erni Ratna. 2018. Metode Pembelajaran Modern Dan Konvensional Pada Sekolah Menengah Atas. Jurnal Ilmu Pendidikan. 2(44-52). (Online).http://ojs.unm.ac.id/pembaljar/article/view/5442(Diakses pada tanggal 18 Maret 2019).

Hapsari, T.R., Vandalita, M.M.R., Makrina T. 2017. Analisis Permasalahan Guru Terkait Perangkat Pembelajaran Berbasis Model Examples Non Examples Dan Permasalahan Siswa Terkait Hasil Belajar Biologi Di SMA.Jurnal Pendidikan. 3(204-209), (Online). http//journal.um.ac.id/jppt.php/JF /article/view File/403/374 (Diakses hari Rabu tanggal 10 Juli 2019).

Kinasih, Arum Mawar. 2017. Problematika Guru Dalam Penyusunan Perangkat Pembelajaran Muhammadiyah 14 Surakarta.(Online).http://eprints.ums.ac.id/50853/1/artikel\%20 publikas.pdf (Diakses pada tanggal 18 Maret 2019)

Suryani., Amining Rahmasiwi., Dewi Puspita Sari., (2015). Peningkatan Keterampilan Proses Sains Peserta didik dalam Pembelajaran Biologi melalui Penerapan Model Pembelajaran Inkuiri di Kelas XI

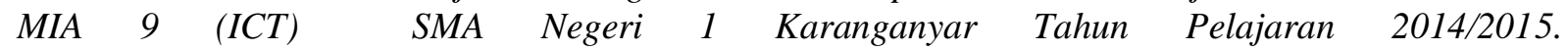
(Online).https://media.neliti.com/media/publications/174936-ID-none.pdf(Diakses pada tanggal 20 Desember 2018).

Trianto, 2010.Model Pembelajaran Terpadu. Jakarta: PT Bumi Aksara.

Pengembangan Perangkat Pembelajaran Biologi Berbasis Keterampilan Proses Sains pada Kelas X IPA

SMA Negeri 2 Majene

(Sainab, dkk) 